\title{
Dehydration of serpentinized slab mantle: Seismic evidence from southwest Japan
}

\author{
Tetsuzo Seno ${ }^{1}$, Dapeng Zhao ${ }^{2}$, Yoji Kobayashi ${ }^{3}$, and Masao Nakamura ${ }^{1}$ \\ ${ }^{1}$ Earthquake Research Institute, University of Tokyo, Tokyo 113-0032, Japan \\ ${ }^{2}$ Department of Earth Sciences, Ehime University, Matsuyama 790-0826, Japan \\ ${ }^{3}$ Faculty of Earth Sciences, Tsukuba University, Tsukuba 305-0006, Japan
}

(Received January 23, 2001; Revised June 4, 2001; Accepted June 12, 2001)

\begin{abstract}
The seismicity in the subducting Philippine Sea slab (PHS) beneath southwest Japan shows a variety of modes of occurrence. We try to explain this variety on the basis of dehydration embrittlement in the subducting oceanic crust and/or mantle. The PHS subducting along the Nankai Trough shows commonly a single narrow seismic zone shallower than $60 \mathrm{~km}$, which may reflect dehydration embrittlement in the hydrated subducting oceanic crust only, implying the lack of hydrated slab mantle. The PHS beneath Kanto, however, shows a double seismic zone (Hori, 1997 ) in the mantle part. Here the serpentinized mantle wedge of the Izu-Bonin fore-arc is subducting, and the double zone can be explained by its dehydration. Beneath Kii Peninsula and Kyushu, seismic events within the slab mantle have also been detected. This indicates that the PHS mantle beneath these areas is also hydrated, which may have resulted from subduction of the serpentine stable in the Izu-Bonin back-arc area. Aqueous fluids released from the serpentinized mantle beneath Kii Peninsula may have initiated partial melting in the mantle wedge, as indicated by the presence of high ${ }^{3} \mathrm{He} /{ }^{4} \mathrm{He}$ ratios in the natural gasses and the shallow seismic swarms in this region (Wakita et al., 1987).
\end{abstract}

\section{Introduction}

The occurrence of intermediate-depth and deep earthquakes at $60-670 \mathrm{~km}$ depth range in the Wadati-Benioff zone is one of the enigmas of earth sciences because the lithostatic pressure at such depths appears to be too high for brittle fracture (see Kirby, 1995 for review). In some slabs, double seismic zones are observed at the depth range of 60 $300 \mathrm{~km}$, often having down-dip compressional (DDC) and down-dip tensional (DDT) stresses in the upper and lower zones, respectively. This suggests that stresses due to unbending (Engdahl and Scholz, 1977), sagging (Sleep, 1979), or thermal expansion (Hamaguchi et al., 1983) may be operating in the slab. However, these alone are not enough to explain the occurrence of such intermediate-depth events because the differential stresses are still too small compared with the high confining pressure. Therefore, some additional mechanisms should be invoked.

Dehydration instability or dehydration embrittlement is one of the most viable mechanisms. Hydrated minerals such as serpentine, epidote, and tremolite show brittle behavior at high temperatures, associated with dehydration, while anhydrous minerals show ductile behavior (Raleigh and Paterson, 1965; Kirby et al., 1990). This would be due to high pore pressures caused by the released water along with microscopic effects of water on crack growth (Kirby, 1995; Kirby et al., 1990). In this study, we discuss the slab seismicity in southwest Japan (Fig. 1), based on the dehydration embrittlement hypothesis, utilizing metamorphic facies diagrams

Copy right (C) The Society of Geomagnetism and Earth, Planetary and Space Sciences (SGEPSS); The Seismological Society of Japan; The Volcanological Society of Japan; The Geodetic Society of Japan; The Japanese Society for Planetary Sciences. of hydrous minerals and temperature structures of the subducting slab.

If dehydration instability is responsible for intermediatedepth earthquakes, it can be classified into two groups; one is dehydration of meta-basalts and meta-gabbros in the subducting oceanic crust, and the other is dehydration of serpentine in the subducting mantle. For serpentine dehydration reactions, in the depth range of $20-70 \mathrm{~km}$, antigorite dehydrates into forsterite-talc first at $600^{\circ}-700^{\circ} \mathrm{C}$, and then transforms into forsterite-enstatite at $670^{\circ}-720^{\circ} \mathrm{C}$, and in the depth range of 70-200 km, antigorite directly dehydrates into forsterite-enstatite at $600^{\circ}-720^{\circ} \mathrm{C}$ (Fig. 2(a), Ulmer and Trommsdorff, 1995). The metamorphic reactions of the hydrous minerals in the oceanic crust are more complex; the reactions occur between the metamorphic facies such as prehnite-actinolite, prehnite-pumpellyite, zeolite, lawsonitechlorite, pumpellyite-actinolite, greenschist, lawsoniteblueschist, epidote-amphibolite, epidote-blueschist, amphibolite, and eclogite (Fig. 2(b), Peacock, 1993).

Near the Japanese islands, the old Pacific plate $(\sim 130 \mathrm{Ma}$, Nakanishi et al., 1992) is subducting beneath northern Honshu, and the young Philippine Sea plate ( $\sim 20 \mathrm{Ma}$, Okino et al., 1994) is descending beneath southwest Japan (Fig. 1). The Pacific slab beneath northern Honshu has a double seismic zone (e.g., Hasegawa et al., 1978), while the slab seismicity beneath southwest Japan is generally shallow (e.g., Nakamura et al., 1997; Yamazaki and Ooida, 1985; Ishida, 1992).

Kirby et al. (1996) explained the upper plane of the double seismic zone beneath northern Honshu by the dehydration in the oceanic crust. On the other hand, Nishiyama (1992) and Seno and Yamanaka (1996) applied the dehydra- 


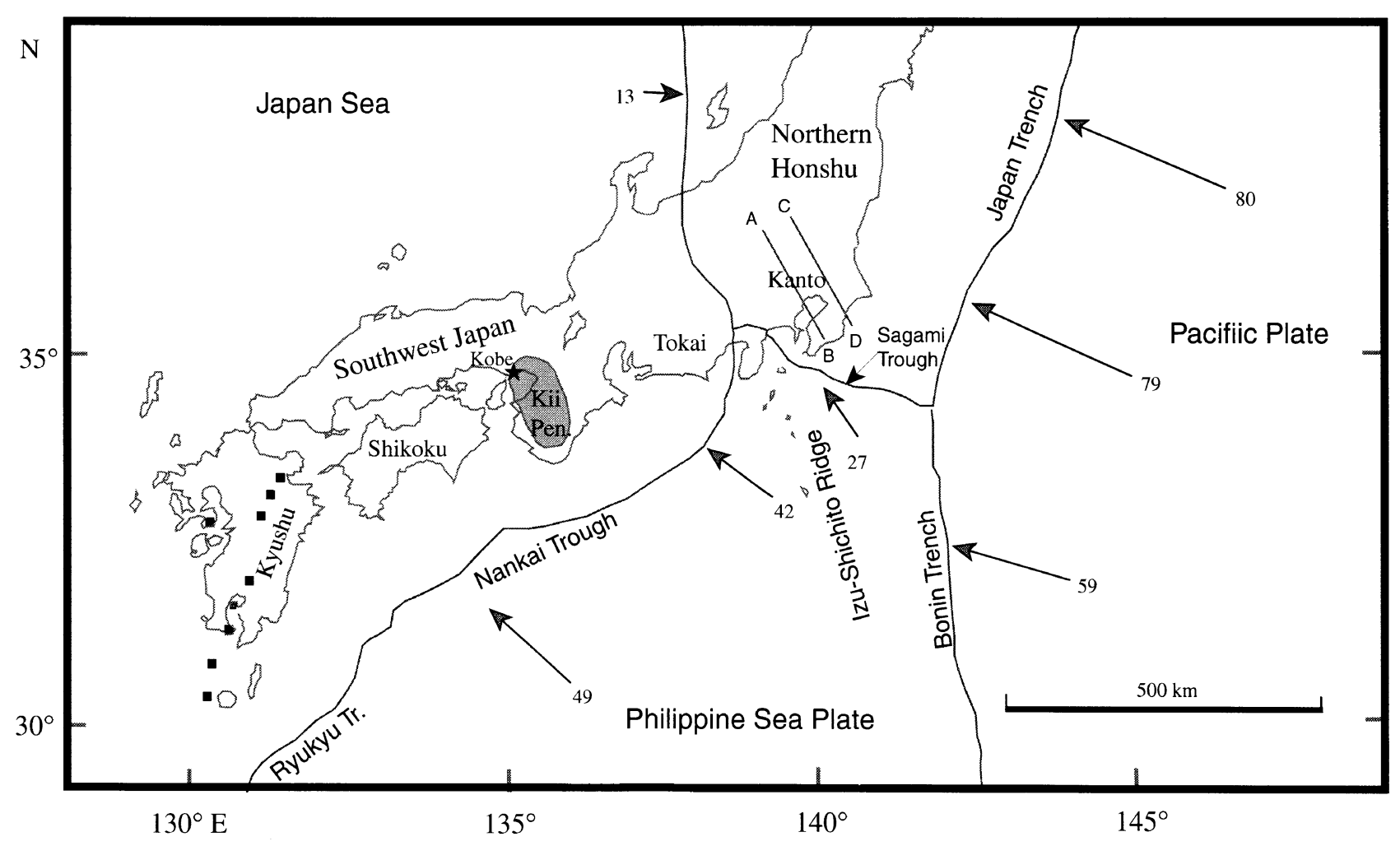

Fig. 1. Index map of southwest Japan. Relative direction and velocity of the motions between the subducting Pacific and Philippine Sea plates and the overriding plates are indicated by the arrows and the numbers (Seno et al., 1993, 1996). High ${ }^{3} \mathrm{He} /{ }^{4} \mathrm{He}$ area (Wakita et al., 1987) is shaded. Solid star indicates the epicenter of the 1995 Kobe earthquake (M 7.2). Lines A-B and C-D show the sections on which seismic activity beneath Kanto are projected in Fig. 6. Active volcanoes in southwest Japan are indicated by solid rectangles.

tion embrittlement of serpentine to the double seismic zone; the double-planed structure of the dehydration locus of the serpentine (Ulmer and Trommsdorff, 1995) accords with the double seismic zone geometry (Seno and Yamanaka, 1996), particularly in the deeper part. Recently Peacock and Wang (1999) discussed the difference in the depth of seismicity and the low velocity layer along the slab between northern Honshu and southwest Japan in terms of the dehydration reactions in the crust based on the temperature structures of the slabs in these regions, and Peacock (2001) stressed the importance of hydration of slab mantle by faulting at the trench-outer rise region on double seismic zone generation.

The Philippine Sea slab (denoted PHS hereinafter) beneath southwest Japan shows a variety of seismicity, more than expected from the dehydration embrittlement of the crust, however. For example, the PHS shows a double seismic zone beneath Kanto (Hori, 1997), and has events deeper than $60 \mathrm{~km}$ beneath some areas (Nakamura et al., 1997). We will show that the dehydration embrittlement of the serpentinized slab mantle can explain their occurrence. We seek a possible cause for the serpentinization of the PHS in such places and discuss their implications for the initiation of arc magmatism.

\section{Slab Seismicity beneath Tokai}

Figure 3 shows the recent microearthquake activity in Tokai (Matsumura, 1997). The westward dipping seismic activity, mostly shallower than $60 \mathrm{~km}$, continues as a single seismic zone. The directions of the $P$-axes (Fig. 3(c)) indicate that they are not thrusting events at the plate interface, and therefore must be within the slab. Fukao et al. (1983) and Hori et al. (1985) argued that the events in this zone occurred within the oceanic crust, not in the mantle, because they accompanied later phases traveling within the crust (Fig. 4).

Wang et al. (1995) calculated the temperature of the subducting PHS at the Nankai Trough beneath Shikoku (Fig. 5). We regard this as a representative temperature structure of the PHS subducting at the Nankai Trough and compare the dehydration loci in the crust and mantle expected from Fig. 2 with the observed seismicity. If the mantle portion of the slab is hydrated at the trench, dehydration may start at a shallow depth such as $20 \mathrm{~km}$, but it may become most effective at the $50-80 \mathrm{~km}$ depth range because the particle motion of the slab material crosses the dehydration loci in this depth range (Fig. 5).

The fact that most of the slab events in Tokai have crustal later phases and the seismic zone is single implies that the mantle part of the PHS subducting beneath Tokai is not hydrated. The normal faulting at the trench-outer rise area would be the most viable mechanism to hydrate the upper portion of a subducting plate (Kirby, 1995; Seno and Yamanaka, 1996). Since there is no conspicuous normal faulting at the trench-outer rise area along the Nankai Trough, anhydrous mantle of the PHS is not mysterious.

In Fig. 2(b), the water content contained in each of the metamorphic facies (Peacock, 1993), and the P-T path of the mid-crust level of the subducting PHS (Wang et al., 1995) 
(a)

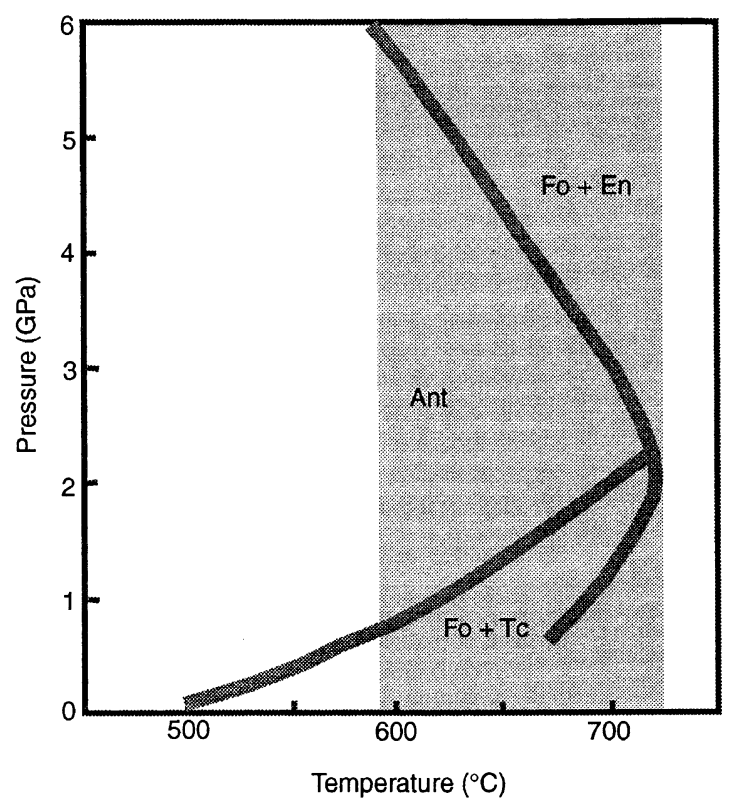

(b)

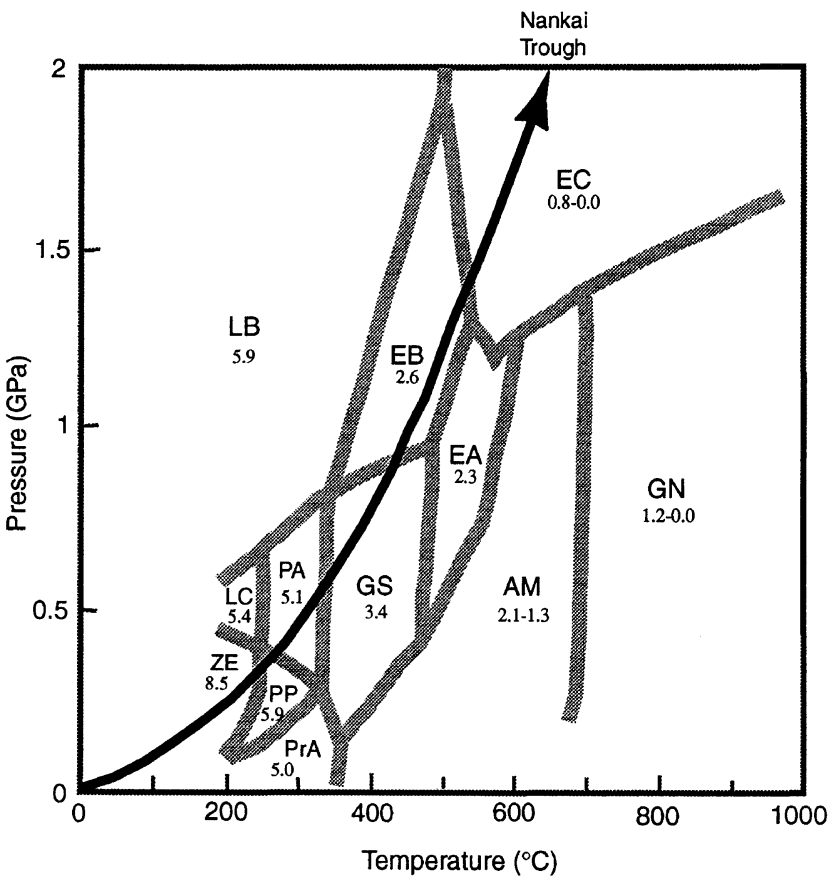

Fig. 2. (a) Pressure-temperature diagram for breakdown of serpentine (adapted from the schematic reaction curves of Ulmer and Trommsdorff, 1995). The dehydration reaction temperature range corresponding to intermediate-depth earthquakes is shaded. Metamorphic facies abbreviations: Ant, antigorite; Fo, forsterite; Tc, talc, and En, enstatite. (b) Pressure-temperature diagram for metamorphic facies of meta-basalt and meta-gabbro (adapted from the compilation of Peacock, 1993). Metamorphic facies abbreviations: AM, amphibolite facies; EA, epidote-amphibolite facies; EB, epidote-blueschist facies; EC, eclogite facies; GN, granulite facies; GS, greenschist facies; LB, lawsonite-blueschist facies; LC, lawsonite-chlorite facies; PP, prehnite-pumpellyite facies; PrA, prehnite-actinolite facies; PA, pumpellyite-actinolite facies; ZE, zeolite facies. For each metamorphic facies, the calculated maximum $\mathrm{H}_{2} \mathrm{O}$ content is shown (wt\%) for a basaltic bulk composition (Peacock, 1993). The P-T path at the mid-crustal level of the subducting Philippine Sea slab (Wang et al., 1995) is shown by a curve with an arrow.

are shown. The P-T path accords with our inference that the single zone of shallow seismicity down to $60 \mathrm{~km}$ beneath Tokai represents successive dehydration reactions in the portion of the crust (see also Peacock and Wang, 1999). In order to cause the dehydration reactions downdip from the $20 \mathrm{~km}$ depth in depth range of the observed slab seismicity, the metamorphic facies in the PHS crust need to contain more than $\sim 4 \mathrm{wt}^{\%} \mathrm{H}_{2} \mathrm{O}$, since greenschist can contain up to $3.4 \mathrm{wt} \% \mathrm{H}_{2} \mathrm{O}$ (Peacock, 1993).

\section{Slab Seismicity beneath Kanto}

In spite of the fact that the same PHS is subducting, there is a striking difference in slab seismicity between Kanto and Tokai. In the PHS beneath Kanto, there is a double seismic zone, which is overlapped by thrust events at the plate interface between the PHS and the overriding plate (northern Honshu) (Fig. 6, Hori, 1997). The stress of the upper plane of the double seismic zone is characterized by DDC and that of the lower plane by DDT (Hori, 1997). In section C-D (Fig. 6(b), see Figs. 6(c) and 1 for location), the two planes merge. Moreover, Hori (1990) showed that the thrust events have later phases traveling within the oceanic crust, but the events in the double seismic zone do not accompany such later phases. This indicates that the double seismic zone events occur in the mantle part of the PHS. Here almost no event occurs within the crust part of the PHS, which is another marked difference from Tokai.

Why is there such a difference between Tokai and Kanto in the PHS seismicity? It should be noted that beneath Kanto, the Izu-Bonin fore-arc is subducting (Fig. 1). Beneath Tokai, in contrast, the Izu-Bonin volcanic ridge, i.e., the Izu-Shichito Ridge, is subducting. Suyehiro et al. (1996) detected a low velocity layer in the fore-arc mantle wedge of the Izu-Bonin arc by seismic refraction surveys and suggested that it represents serpentine, consistent with the serpentine seamounts-diapirs seen at the landward trench slope (Fryer and Fryer, 1987; Kamimura et al., 2001). Therefore the events in the mantle part of the PHS beneath Kanto may have resulted from dehydration embrittlement of the subducted fore-arc made of serpentine.

We shade the serpentine stability field in the thermal structure calculated by Honda (1985) for northern Honshu (Fig. 7); the $30 \mathrm{~km}$ crustal thickness of northern Honshu is modified to the $20 \mathrm{~km}$ thickness of the Bonin arc of Suyehiro et al. (1996). This is justified because in these regions, the subducting Pacific plate has the similar age (ca. $130 \mathrm{Ma}$, Nakanishi et al., 1992) and dip angle, and the observed heat flows in the forearc are also similar (Yamano, 1995). The isotherms in the stability field of the fore-arc wedge show a curved structure with a higher temperature at the inside of the corner. If the serpentinized wedge with such a thermal structure subducts beneath Kanto, the portion reaching the dehydration temperature $\left(\sim 650^{\circ} \mathrm{C}\right)$ would become double-planed, and the associated embrittlement would produce a double seismic zone as observed. Further- 
(a)

(b)
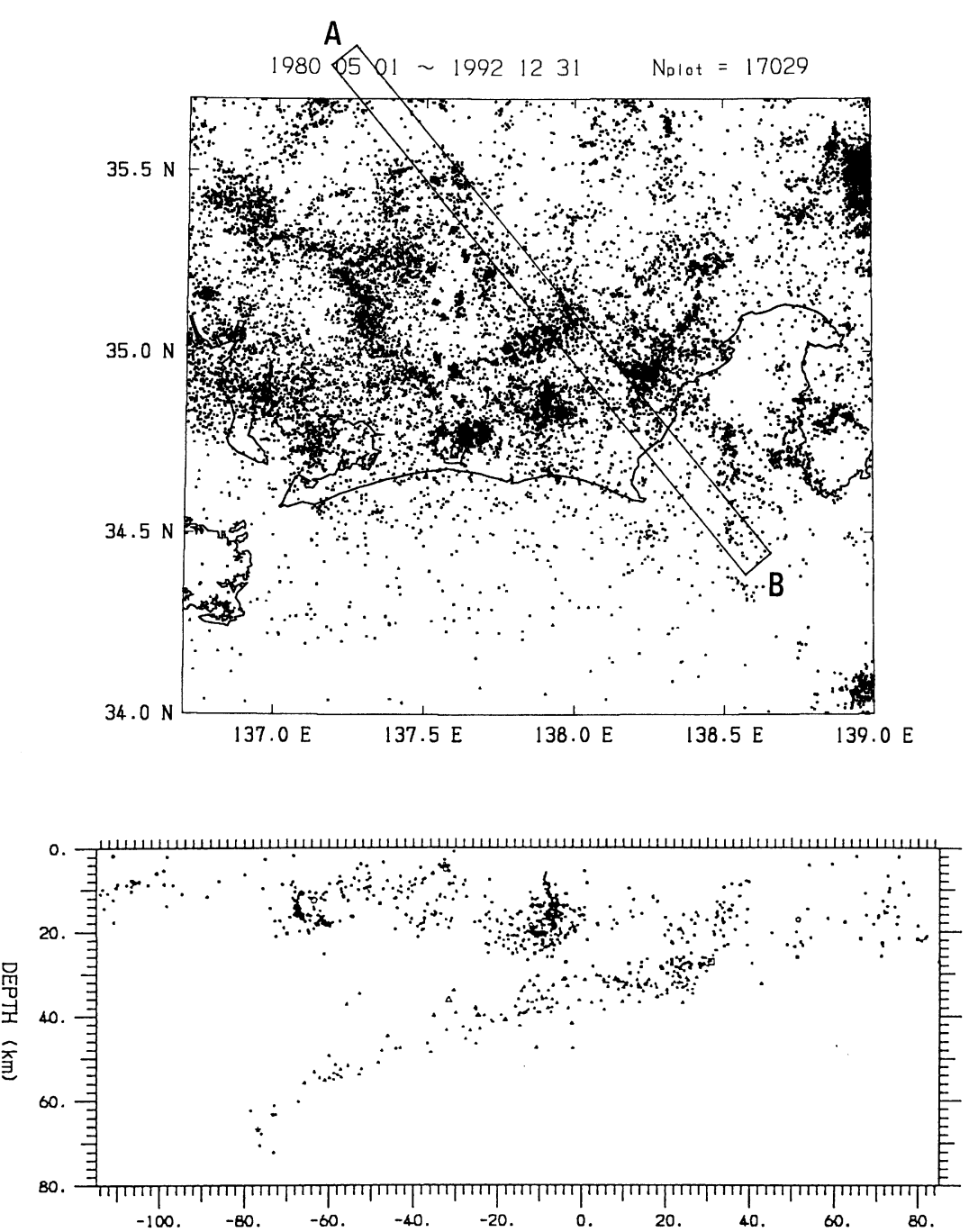

(c)

HORIZONTAL DIST $(\mathrm{km})$

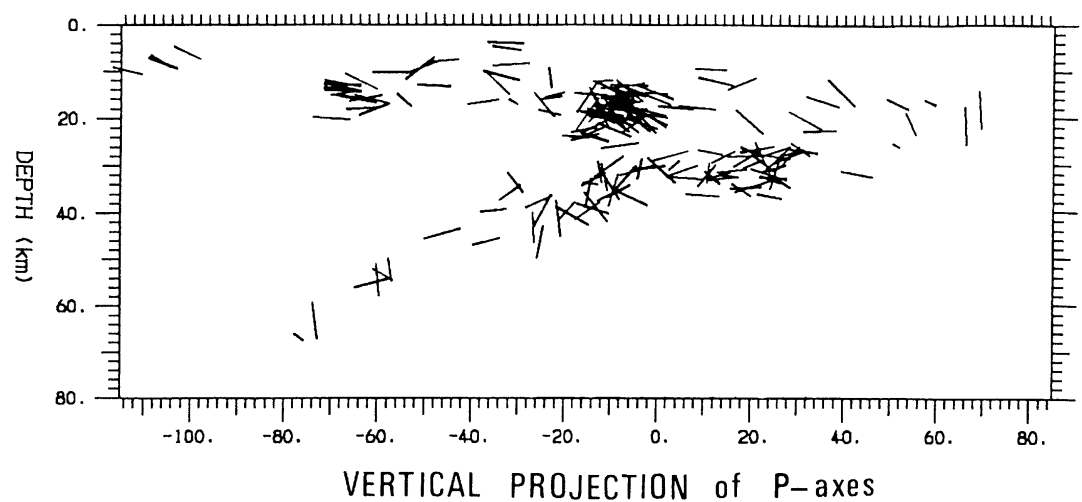

Fig. 3. Microearthquake activity from May 1980 through December 1992 in the Tokai district detected by the network of the Disaster Prevention Research Institute, Science and Technology Agency, Japan (Matsumura, 1997): (a) epicentral distribution, (b) vertical cross-section of the hypocenters along line A-B shown in (a), and (c) the same as (b) but showing the projection of the $P$-axes.

more, the distance between the upper and lower planes is expected to become narrower on the trench side, as observed in Fig. 6(b).

The apparent velocities of the first arrivals of the seis- mic waves coming from the thrust events in Kanto further supports the subduction of the serpentinized mantle. They travel in the upper part of the slab mantle and have the average apparent velocity of $7.7 \mathrm{~km} / \mathrm{sec}$ (Hori, 1990), which 
(a)

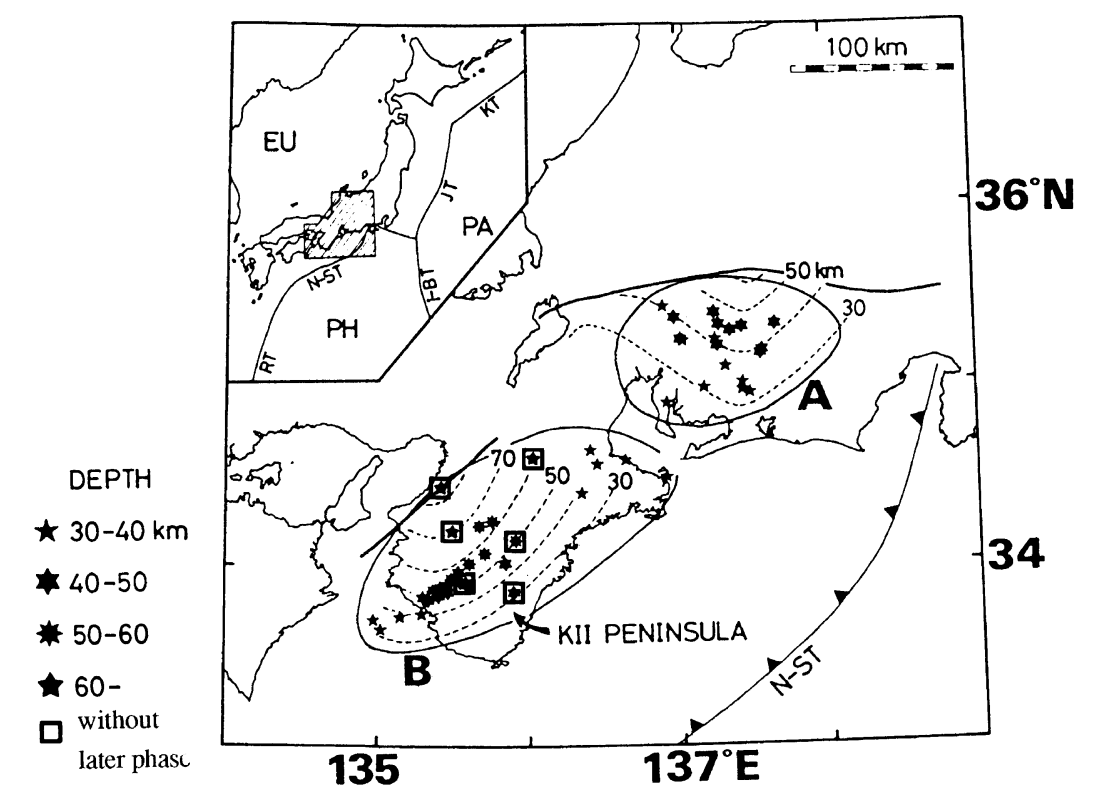

(b)

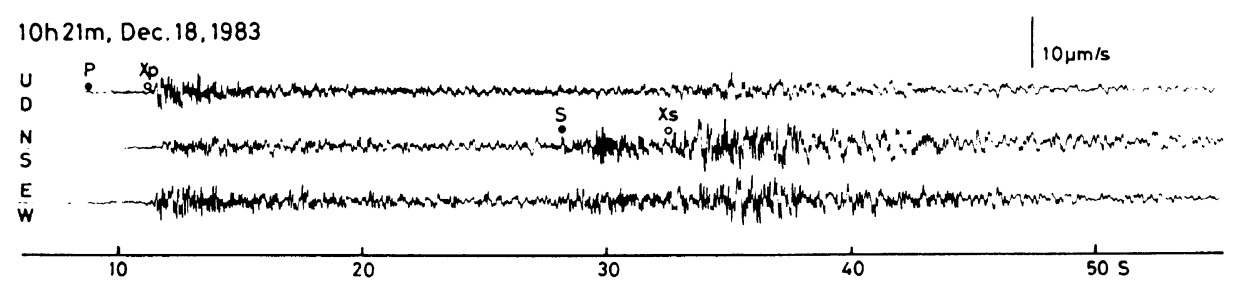

Fig. 4. (a) Slab events studied by Hori et al. (1985) in the Tokai and Kii Peninsula areas. Symbols are classified by the focal depths. The events without later phases are detected in the Kii Peninsula area B which are marked by the rectangles. The dotted lines indicate the depth contours of the upper surface of the seismic zone. The symbol abbreviations: EU, Eurasian plate; PA, Pacific plate; PH, Philippine Sea plate; KT, Kuril Trench, I-B T, Izu-Bonin Trench; RT, Ryukyu Trench; N-ST, Nankai-Suruga Trough. (b) Example of the later phases after $P$ and $S$ waves (Xp, Xs), which were confirmed to the phases traveling through the low velocity crust of the subducting Philippine Sea slab (Hori et al., 1985).

is much slower than that from the oceanic crust events in Tokai, i.e., $8.1 \mathrm{~km} / \mathrm{sec}$ (Hori et al., 1985). Using the incident angles of $60-70^{\circ}$ beneath Kanto (figure 14 of Hori, 1990), we obtain an in-situ slab mantle $P$-wave velocity of $6.7-7.2$ $\mathrm{km} / \mathrm{sec}$, which coincides with the velocity of the Izu-Bonin fore-arc wedge estimated by Suyehiro et al. (1996). This velocity corresponds to that of serpentine hydrated by $70-50 \%$ (Hess, 1962; Christensen, 1966). In contrast, beneath Tokai, Hori et al. (1985) obtained a $P$-wave velocity of $8.0 \mathrm{~km} / \mathrm{sec}$ for the mantle part of the PHS, using a ray tracing method.

The release of $\mathrm{H}_{2} \mathrm{O}$ from the serpentine in the mantle would cause $\mathrm{H}_{2} \mathrm{O}$ saturation in the crust just above the dehydration zone, and might have resulted in the retardation of the dehydration reactions in the crust (see Ahrens and Schubert, 1975), reducing seismicity in the subducting crust. To discuss this effect more qualitatively, we have to know better the processes of aqueous fluid migration in the crust and mantle associated with dehydration-hydration reactions, which is beyond the scope of the present study.

Kamiya and Kobayashi (2000) and Sekiguchi (2000) found regions with high Poisson's ratio just above the sub-

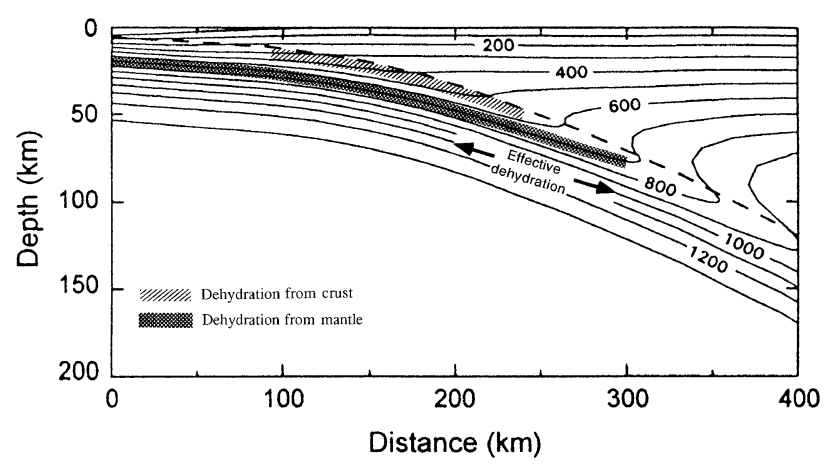

Fig. 5. Dehydration loci are drawn in the temperature structure calculated by Wang et al. (1995) for the Philippine Sea slab subducting along the Nankai Trough beneath Shikoku. The slab temperature was calculated using a transient model in which the $0 \mathrm{Ma}$ age crust started to subduct at $15 \mathrm{Ma}$. The dehydration loci are based on Fig. 2. The effective dehydration zone from serpentinized mantle at the $40-80 \mathrm{~km}$ depth range is indicated by the double arrow. 
(a)

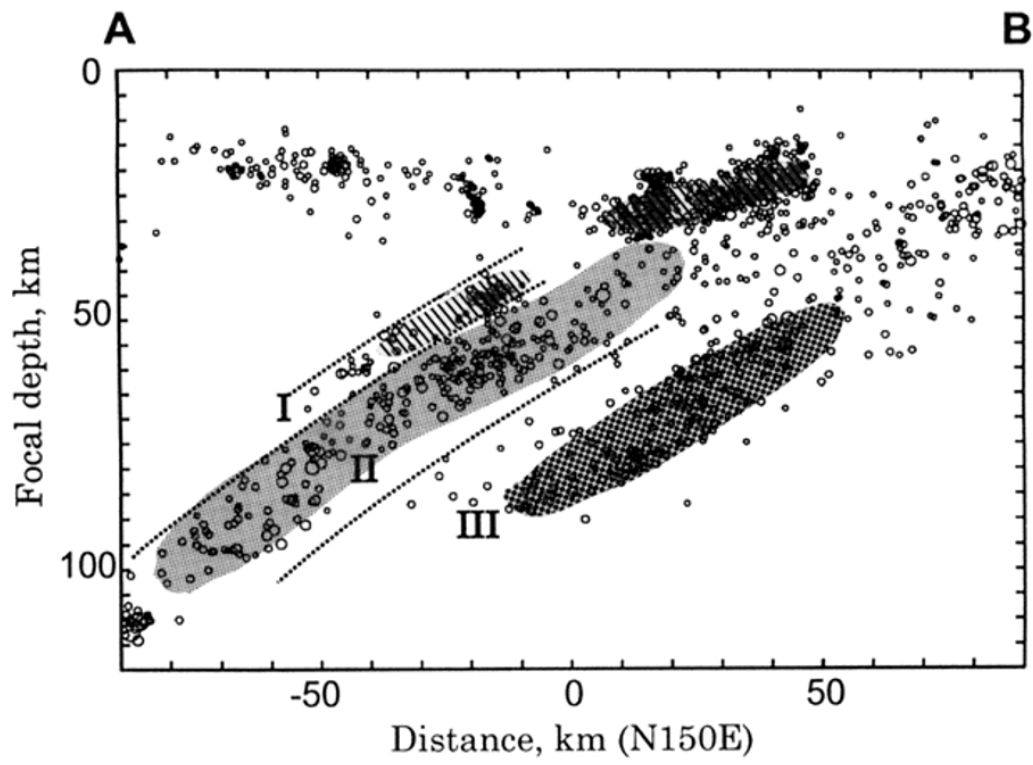

(b)

(c)
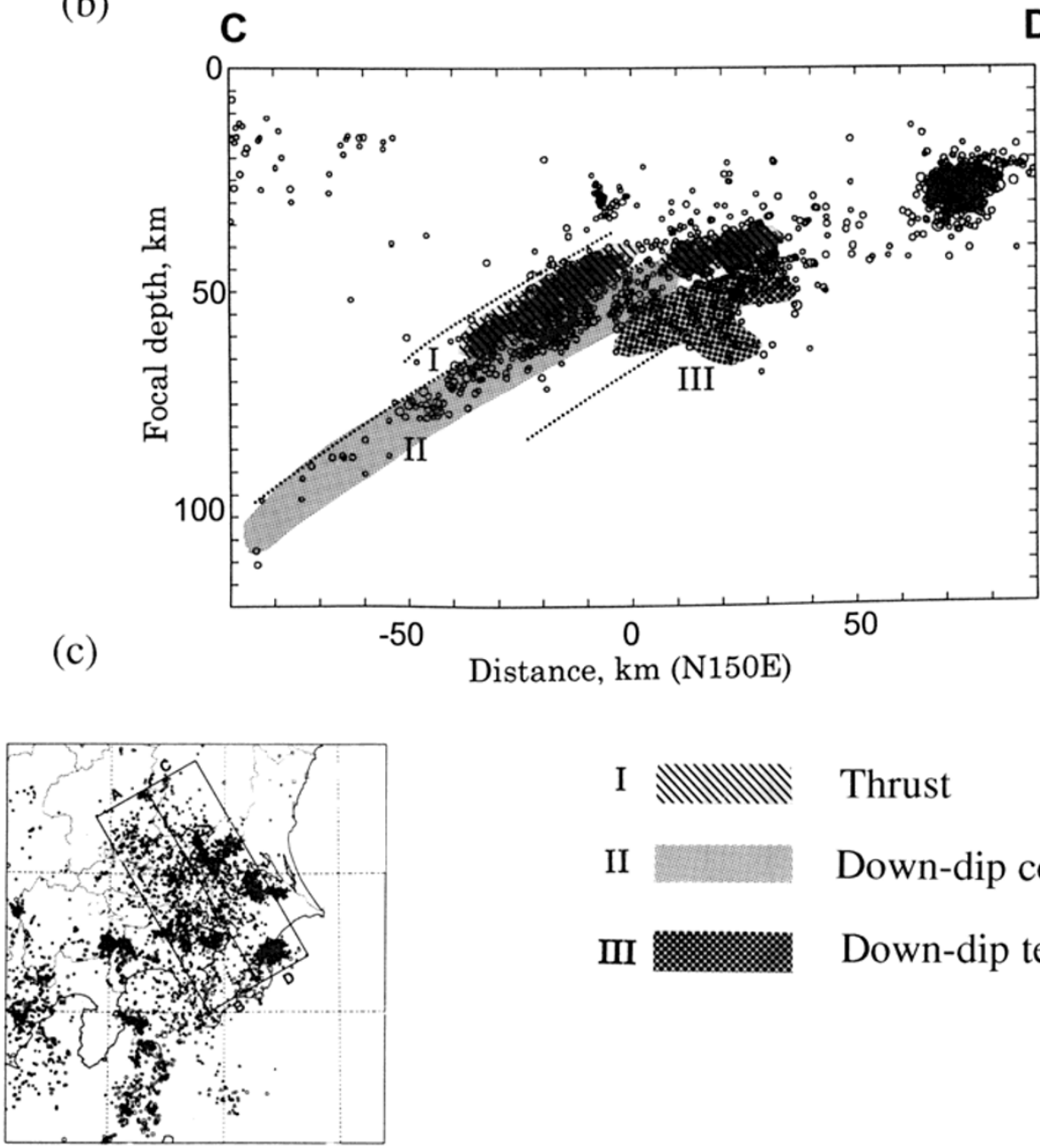

I $\mathbb{M} M+M$ Thrust

II Down-dip compression

III

Down-dip tension

Fig. 6. Cross-sections of the seismicity (during ca. 10 years since Apr. 1986) within the Philippine Sea plate and the upper plate, detected by the network of the Disaster Prevention Research Institute, Science and Technology Agency, Japan (modified from Hori, 1997). Locations of vertical sections (a) A-B and (b) C-D are shown in (c) and also in Fig. 1. The events within the Philippine Sea slab are classified into three groups: (I) thrust at the plate interface, (II) down-dip compression, and (III) down-dip tension (Hori, 1997). 


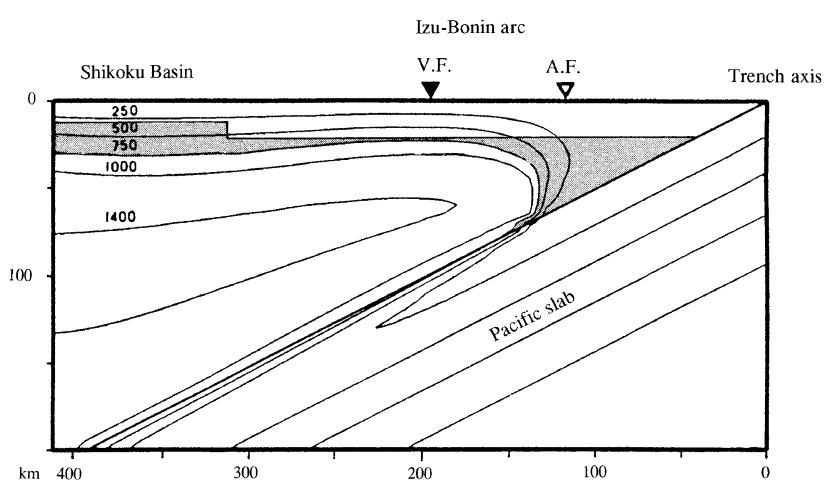

Fig. 7. Serpentine stability fields in the section of the Bonin arc-Shikoku Basin (shaded area). The dehydration temperature (Fig. 2(a)) is simplified to be $750^{\circ} \mathrm{C}$. The temperature structure calculated for the northern Honshu section (Honda, 1985, model S1L3A7T1) is used by modifying the crustal thickness to be $20 \mathrm{~km}$ (Suyehiro et al., 1996). There are two stability fields: one in the fore-arc wedge mantle, the other in the Shikoku Basin.

ducting Philippine Sea slab by seismic tomography methods using $P$ and $S$ wave arrival times, and suggested existence of dehydration from the slab. Although it is difficult to identify the origin of the high Poisson's ratio, the extensive occurrence of the slab mantle events, possibly with dehydration, beneath Kanto appears to be consistent with their tomography results.

\section{Slab Seismicity beneath Kii Peninsula and Kyushu}

The seismicity within the PHS along other parts of the Nankai Trough is similar to that beneath Tokai, that is, it shows a single zone shallower than $60 \mathrm{~km}$ (e.g., Nakamura et al., 1997). However, there is one exceptional area, i.e., Kii Peninsula where slab events occur down to a depth of 80 $\mathrm{km}$, deeper than in the other areas (Nakamura et al., 1997). Moreover, in this area, Hori et al. (1985) detected events that do not accompany later crustal phases. Those events without later phases are indicated by rectangles in Fig. 4; their depths are generally greater than $50 \mathrm{~km}$ but not necessarily located at the deepest portion of the seismic slab.

Fukao et al. (1983) and Hori et al. (1985) interpreted these events as representing the transformation of basalt to eclogite in the crust of the subducting PHS. If this interpretation is correct, they are expected to occur at the deepest portion from the facies diagram shown in Fig. 2(b), which is not as observed. It is also expected that they do accompany later crustal phases because they are still within the oceanic crust; T. Ohkura (personal. comm., 2000) indeed confirmed, by numerical simulation using a ray tracing method, that, if they are in the crust, they must accompany later phases. These arguments thus suggest that those events beneath Kii Peninsula without later phases occurred within the mantle portion of the PHS. This implies in turn that, beneath Kii Peninsula, dehydration of the serpentinized mantle of the PHS is occurring, and that the mantle portion of the PHS subducting beneath this area was hydrated before subduction.

Recent seismic tomography results (Zhao et al., 2000c) show a significant low-velocity zone $(-6 \%)$ with a lateral extent of 50-100 km within the PHS beneath Kii Peninsula (Fig. 8). In other areas along the Nankai Trough, the PHS is detected as high velocity anomalies $(+6 \%)$. Detailed resolution analyses show that the low-velocity zone beneath Kii Peninsula is a robust feature. Many of the slab events are located within this low-velocity zone; thus, this low-velocity zone may not be a temperature anomaly. It is probably caused by the serpentinization of the slab mantle and subsequent dehydration, as proposed above.

Kyushu is located at the northernmost end of the Ryukyu Trench, at the junction with the Nankai Trough (Fig. 1). Ohkura (2000) detected slab events without later phases beneath the northeastern corner of Kyushu; they are all deeper than $60 \mathrm{~km}$. Therefore it is inferred that the PHS mantle subducting beneath Kyushu is also hydrated producing mantle dehydration events. Beneath central Kyushu, slab seismicity occurs down to a depth of $160 \mathrm{~km}$ (Shimizu et al., 2000) and active andesite volcanoes appear on land (Fig. 1). Seismic tomography results (Zhao et al., 2000a) show marked low velocities in the mantle wedge which may represent partial melting induced by the released $\mathrm{H}_{2} \mathrm{O}$ from the slab. The tomography also shows that the slab mantle at 90-120 km depth range has a moderately low velocity (figure $2 \mathrm{~d}$ of Zhao et al., 2000a). Many seismic events are located within that portion of the zone, similar to those beneath Kii Peninsula, suggesting that mantle dehydration events occur there. Although the remnant arc (Palau-Kyushu Ridge) (Fig. 9) subducting beneath Kyushu makes the thermal structure of the PHS unclear there, it is older ( $\sim 50 \mathrm{Ma}$, see Seno, 1988) than the Shikoku Basin subducting along the Nankai Trough ( 20 Ma, e.g., Okino et al., 1994). The colder slab would develop the dehydration locus of serpentine more significantly at depth than shown in Fig. 5, if the mantle part of the PHS is hydrated. Thus the state beneath Kyushu might be regarded as an advanced stage of what is beneath Kii Peninsula.

It should be noted that Sano and Wakita (1985) and Wakita et al. (1987) already pointed out a possibility of renewed magmatism in the area of Kii Peninsula. They showed that the values of ${ }^{3} \mathrm{He} /{ }^{4} \mathrm{He}$ measured for natural gasses from water wells, hot springs, and cold springs, etc, are anomalously high in this area in spite of the fore-arc locations (see Fig. 1 for the location of the high ${ }^{3} \mathrm{He} /{ }^{4} \mathrm{He}$ area). The values are similar to those measured in the volcanic areas in Japan, showing that sources of the gasses are affected by magmas. They further cited evidence to support this, such as converted seismic phases from the discontinuity in the lower crust, shallow seismic swarms in the upper crust, high heat flows, and high temperature hot springs.

Our results presented above basically support their inference, because the dehydration from the serpentinized mantle occurring in the $50-80 \mathrm{~km}$ depth range (Fig. 4) provides $\mathrm{H}_{2} \mathrm{O}$ to the mantle wedge above it, and may lead to partial melting in the mantle wedge. If incipient partial melting is taking place in the mantle beneath Kii Peninsula, this provides a case showing that the release of $\mathrm{H}_{2} \mathrm{O}$ from the serpentinized mantle is an important factor for the generation of arc magmas (Ulmer and Trommsdorff, 1995), in addition to that from the subducting oceanic crust (Tatsumi, 1989; 

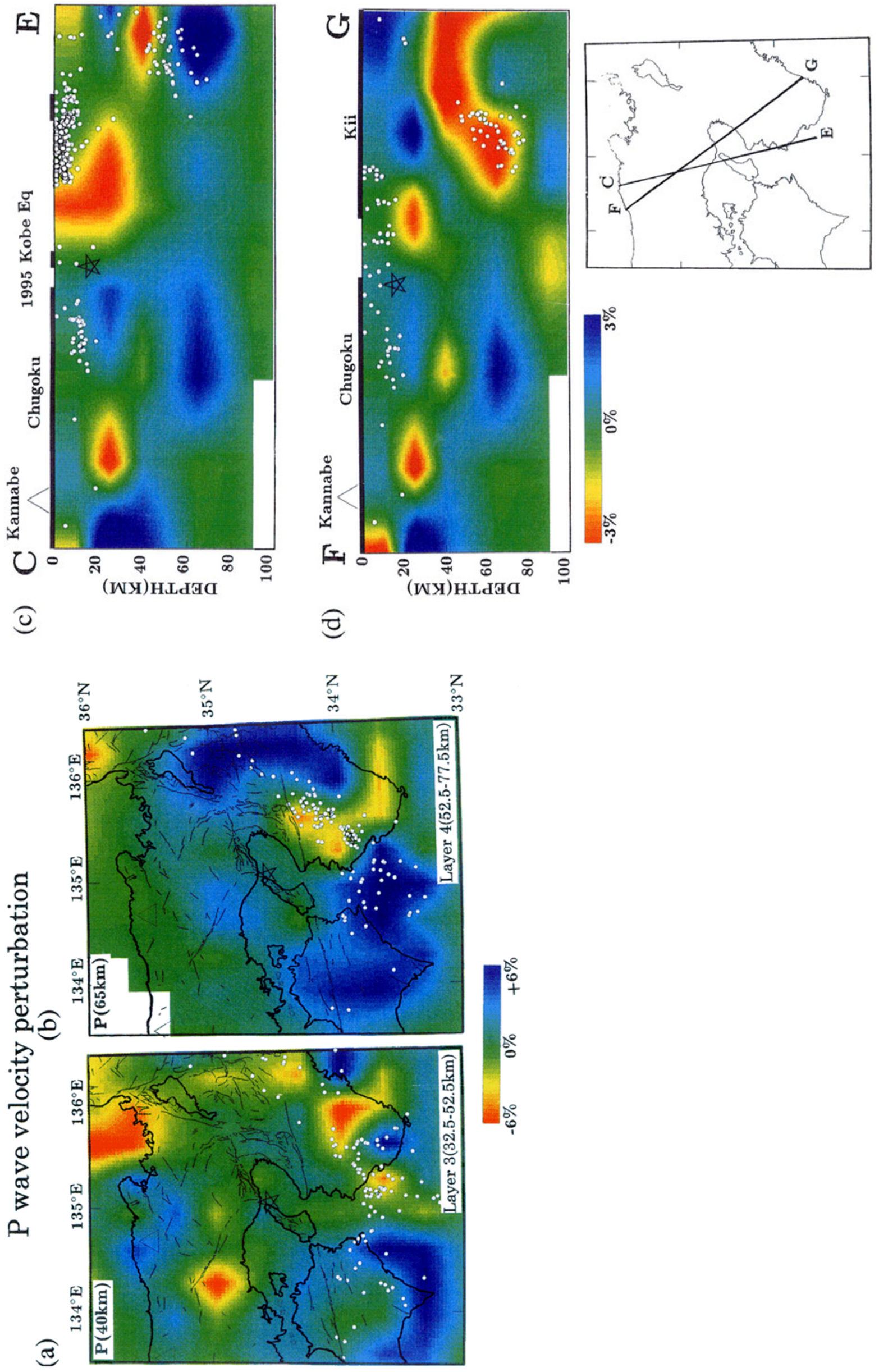

눌

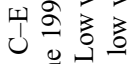

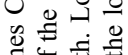

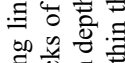

흐을

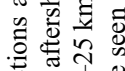

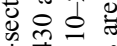

证语

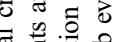

峞

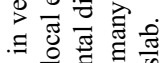

要过

ตำ ते

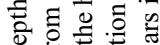

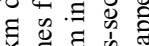

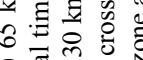

อ.

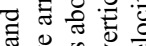

Q +

ब的言官

ब $\overline{0}$ है

20

记

$\stackrel{0}{=} 0$

语的

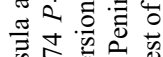

定河

o in

运完

逑

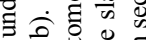

훙의

훙ㅎํ

范

के 5

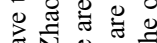

政

$\infty$ 政 oid 


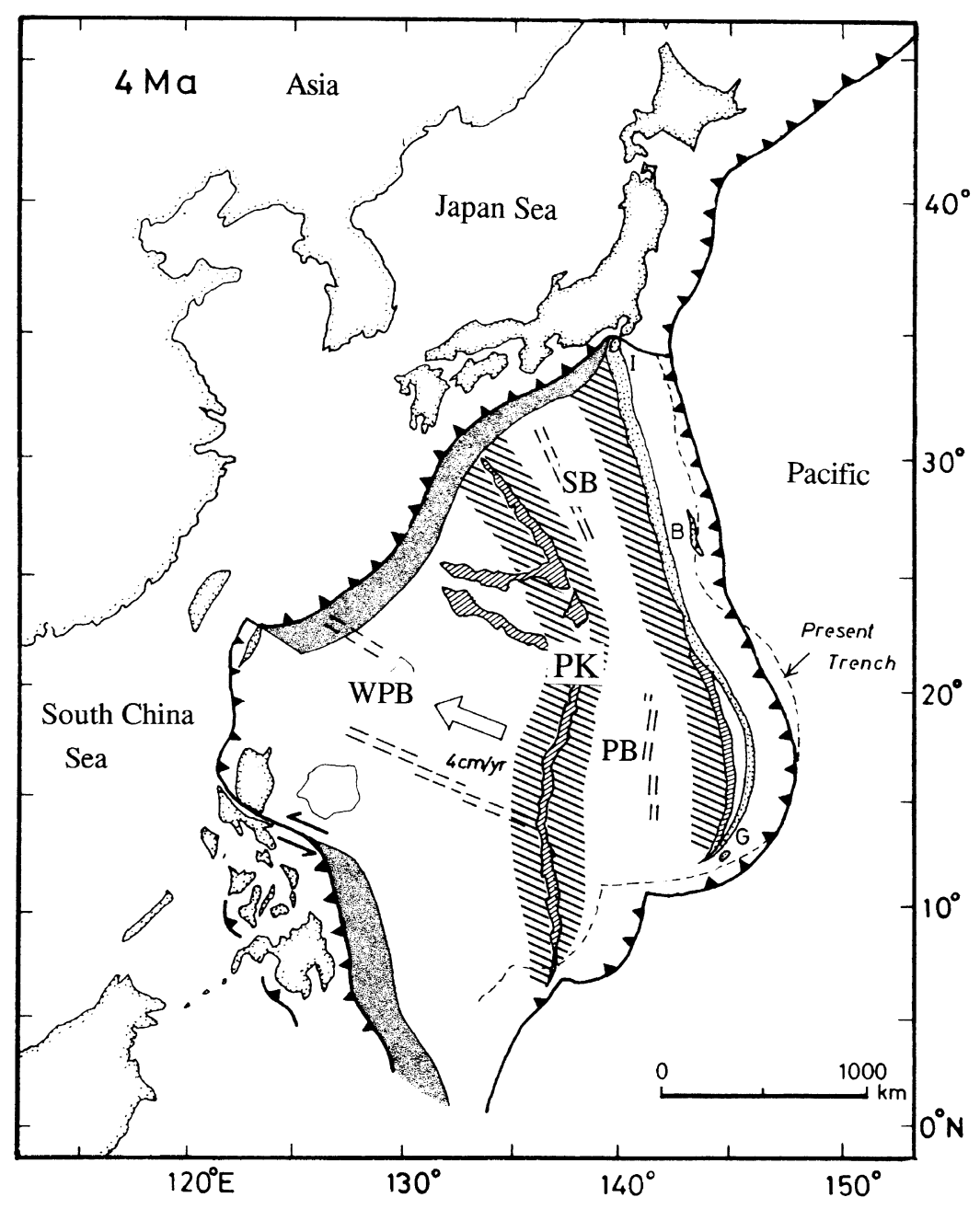

Fig. 9. Regions of possible serpentinized mantle in the back-arc areas of the Izu-Bonin arc are hachured in the 4 Ma reconstruction of the Philippine Sea (Seno and Maruyama, 1984). It is assumed that the serpentinization was induced by diapirs associated with the back-arc volcanism. The exact boundaries are uncertain. The shaded area is part of the Philippine Sea plate subducted since 4 Ma. The symbol abbreviations: PK, Palau-Kyushu Ridge; SB, Shikoku Basin; PB, Parece Vela Basin; WPB, West Philippine Basin.

Davies and Stevenson, 1992; Iwamori, 1998), because beneath the other areas along the Nankai Trough, where dehydration from the subducting crust is occurring, there is no sign of the generation of arc magmas.

The release of $\mathrm{H}_{2} \mathrm{O}$ from the serpentinized mantle and the possible incipient partial melting might also have a causal relationship with large crustal earthquakes in southwest Japan such as the 1995 Kobe earthquake (M 7.2). Zhao and Negishi (1998) determined high-resolution 3-D $P$ and $S$ wave velocity and Poisson's ratio structures in the Kobe source area and showed that the Kobe mainshock hypocenter is located in a distinctive zone characterized by low $P$ and $S$ wave velocities and high Poisson's ratio. Zhao et al. (2000b), using a tomographic inversion beneath Shikoku, showed, in the south of the Kobe source region, another zone with low $P$ and $S$ wave velocities and high Poisson's ratio, horizontally lying at around $25 \mathrm{~km}$ depth above the subducting PHS, and suggested that fluids dehydrated from the PHS might be related to the Kobe earthquake. It is interesting to note that the high ${ }^{3} \mathrm{He} /{ }^{4} \mathrm{He}$ area of Wakita et al. (1987) just covers the Kobe earthquake source region in the north (Fig. 1). Although it is difficult to determine the exact origin of the fluids in the hypocenter area at present, we infer that the fluids dehydrated from the serpentinized mantle of the PHS might be somehow causally related to the occurrence of the Kobe earthquake.

Why are the segments of the PHS subducting only beneath Kii Peninsula and Kyushu hydrated? In the thermal structure model of the Izu-Bonin arc (Fig. 7), of which we shaded the serpentine stability field, there is another serpentine stability field in addition to the fore-arc wedge. The crust thins in the Shikoku Basin at about $120 \mathrm{~km}$ west of the volcanic front (Suyehiro et al., 1996; Takahashi et al., 1998). Beneath this thin oceanic crust a serpentine stability field exists; in contrast, beneath the Izu-Bonin volcanic ridge, the thicker crust prohibits serpentine stability. The seismic refraction study across the Izu-Bonin ridge shows a $7.0-7.4 \mathrm{~km} / \mathrm{sec}$ layer at the base of the Shikoku Basin crust (Takahashi et al., 1998), of which velocity is significantly higher than the lower crust velocity of the Shikoku Basin (6.7 km/sec, Murauchi et al., 1968), suggesting serpentinization there. We guess that beneath the Shikoku Basin close to the volcanic ridge, mantle diapirs associated with arc magmatism would rise up and crystallize beneath 
the crust, releasing $\mathrm{H}_{2} \mathrm{O}$ from the partial melts, resulting in hydration of the surrounding mantle. In the central part of the basin, this hydration is not expected because of the higher geotherm and lack of back-arc volcanism.

If this scenario is accepted, the serpentinized mantle would have formed prior to $30 \mathrm{Ma}$ in the back-arc west of the Palau-Kyushu Ridge because at this time, subduction occurred from the east beneath this ridge (Seno and Maruyama, 1984). During and after the formation of the Shikoku Basin since 30 Ma (Okino et al., 1994), the serpentinized mantle would have formed at both margins of the Shikoku Basin. Figure 9 presents an example of possibly hydrated areas as hachured in the $4 \mathrm{Ma}$ reconstruction of the Philippine Sea plate (Seno and Maruyama, 1984). We then expect that hydrated portions of the PHS might have been subducting sine 4 Ma beneath only Kii Peninsula and Kyushu.

Finally we add here that Kodaira et al. (2001) recently identified a narrow zone of seismic activity in the slab mantle beneath eastern Shikoku, where the Kinan seamount chain is subducting. They attributed the hydration there to possible plume activities beneath the Kinan seamounts, based on Seno and Yamanaka (1996)'s hydration hypothesis.

\section{Conclusions}

The seismicity in the subducting PHS beneath southwest Japan along the Nankai Trough shows generally a single zone shallower than $60 \mathrm{~km}$, but a double seismic zone beneath Kanto and deeper events beneath Kii Peninsula and Kyushu. We try to explain this variety on the basis of dehydration embrittlement in the subducting oceanic crust and/or mantle.

The single seismic zone shallower than $60 \mathrm{~km}$ may represent the dehydration embrittlement in the subducting oceanic crust, implying that the mantle part of the PHS is not hydrated. Beneath Kanto, however, the Izu-Bonin fore-arc mantle wedge, which is likely to be serpentinized, is subducting, and the double seismic zone can be explained by the dehydration of the serpentinized wedge corner. Deep events down to $80 \mathrm{~km}$, events which do not accompany the crustal later phases, and low-velocity patches are detected within the mantle slab beneath Kii Peninsula, indicating that the dehydration embrittlement of the serpentine occurs beneath Kii Peninsula. Aqueous fluids released from the serpentinized mantle beneath Kii Peninsula may have initiated partial melting in the mantle wedge, as observed in the high ${ }^{3} \mathrm{He} /{ }^{4} \mathrm{He}$ ratios in the natural gasses, shallow seismic swarms, and high temperature hot springs in this region. Deeper seismicity and the events without later crustal phases beneath Kyushu and the seismic tomography suggest that dehydration of the slab mantle occurs also beneath Kyushu, which would be in an advanced stage of Kii Peninsula. The PHS mantle subducting beneath both of the areas is likely to have been hydrated due to the back-arc volcanism in the Shikoku Basin behind the Izu-Bonin arc.

Acknowledgments. We thank Kelin Wang and Sadaki Hori for critical reviews. We also thank Yoshiro Nishio for information on the geochemistry data in Kii Peninsula, Takahiro Okura for in- formation on the crustal phases of the Philippine Sea slab events, Shuichi Kodaira for preprint, Atsuki Kubo, Toru Matsuzawa, and Steve Kirby for discussion.

\section{References}

Ahrens, T. J. and G. Schubert, Gabbro-eclogite reaction rate and its geophysical significance, Reviews of Geophysics and Space Physics, 2, 383400, 1975.

Christensen, N. I., Elasticity of ultrabasic rocks, J. Geophys. Res., 71, 5921-5931, 1966

Davies, J. H. and D. J. Stevenson, Physical model of source region of subduction zone volcanics, J. Geophys. Res., 97, 2037-2070, 1992.

Engdahl, E. R. and C. H. Scholz, A double Benioff zone beneath the central Aleutians: An unbending of the lithosphere, Geophys. Res. Lett., 4, 473476, 1977.

Fryer, P. and G. Fryer, Origins of nonvolcanic seamounts in a fore-arc environment, in Seamounts Islands and Atolls, edited by H. Keating, P. Fryer, R. Batiza, and G. W. Boehlert, pp. 61-69, Am. Geophys. Union, Washington, D. C., 1987.

Fukao, Y., S. Hori, and M. Ukawa, A seismological constraint on the depth of basalt-eclogite transition in a subducting oceanic crust, Nature, 303, 413-415, 1983.

Hamaguchi, H., H. Goto, and Z. Suzuki, Double-planed structure of intermediate depth seismic zone and thermal stress in the descending plate, J. Phys. Earth, 31, 329-347, 1983.

Hasegawa, A., N. Umino, and A. Takagi, Double-planed structure of the deep seismic zone in the northeastern Japan arc, Tectonophys., 47, 43$58,1978$.

Hess, H. H., History of ocean basins, in Petrological Studies; A Volume in Honor of A. F. Buddington, edited by A. E. Engel, H. L. James, and B. F. Leonard, pp. 599-620, Geol. Soc. Am., Boulder, 1962.

Honda, S., Thermal structure beneath Tohoku, northeast Japan - a case study for understanding the detailed thermal structure of the subdution zone, Tectonophys., 112, 69-102, 1985.

Hori, S., Seismic waves guided by untransformed oceanic crust subducting into the mantle: the case of the Kanto district, central Japan, Tectonophys., 176, 355-376, 1990.

Hori, S., Earthquake mechanism within the Philippine Sea plate subducting beneath the Kanto district, central Japan, Jisin, 50, 203-213, 1997 (in Japanese).

Hori, S., H. Inoue, Y. Fukao, and M. Ukawa, Seismic detection of the untransformed 'basaltic' oceanic crust subducting into the mantle, Geophys. J. R. astron. Soc., 83, 169-197, 1985.

Ishida, M., Geometry and relative motion of the Phillippine sea plate and Pacific plate beneath the Kanto-Tokai district, Japan, J. Geophys. Res., 97, 489-513, 1992.

Iwamori, $\mathrm{H}$., Transportation of $\mathrm{H}_{2} \mathrm{O}$ and melting in subduction zone, Earth Planet. Sci. Lett., 160, 65-80, 1998.

Kamimura, A., J. Kasahara, R. Hino, M. Shinohara, H. Shiobara, G. Fujie, and T. Kanazawa, Crustal structure study at the Izu-Bonin subduction zone around $31^{\circ} \mathrm{N}$ Implications of serpentinized materials along the subduction plate boundary, Scientific activities 2001, Istanbul Technical University, 21-30, 2001.

Kamiya, S. and Y. Kobayashi, Seismological evidence for the existence of serpentinized wedge mantle, Geophys. Res. Lett., 27, 819-822, 2000.

Kirby, S., Intraslab earthquakes and phase changes in subducting lithosphere, Rev. Geophys., Suppl., 287-297, 1995.

Kirby, S., B. S. Hemingway, and R. Lee, Anomalous fracture and thermal behavior of hydrous minerals, Geophys. Monogr., 56, 119-126, 1990.

Kirby, S., E. R. Engdhal, and R. Denlinger, Intermediate-depth intraslab earthquakes and arc volcanism as physical expressions of crustal and uppermost mantle metamorphism in subducting slabs (Overview), edited by G. Bebout, D. Scholl, and S. Kirby, Geophys. Monogr., 96, 195-214, Am. Geophys. Union, Washington, D. C., 1996.

Kodaira, S., E. Kurashimo, N. Takahashi, A. Nakanishi, S. Miura, J.-O. Park, T. Iwasaki, N. Hirata, K. Ito, and Y. Kaneda, Structural factors in controlling a rupture process of a magathrust earthquake at the Nankai trough seismogenic zone: results from asn onshore-offshore seismic study, Geophys. J. Inter., 2001 (submitted).

Murauchi, S., N. Den, S. Asano, H. Hotta, T. Yoshii, T. Asanuma, K. Hagiwara, K. Ichikawa, T. Sato, W. J. Ludwig, J. I. Ewing, N. T. Edgar, and R. E. Houtz, Crustal structure of the Philippine Sea, J. Geophys. Res., 73, 3143-3171, 1968.

Matsumura, S., Focal zone of a future Tokai earthquake inferred from the seismicity pattern around the plate interface, Tectonophys., 273, 271- 
291, 1997

Nakamura, M., H. Watanabe, T. Konomi, S. Kimura, and K. Miura, Characteristics activities of subcrustal earthquakes along the outer zone of southwestern Japan, Annuals of the Disaster Prevension Research Instutute, 40, 1-20, 1997 (in Japanese).

Nakanishi, M., K. Tamaki, and K. Kobayashi, A new Mesozoic isochron chart of the northwestern Pacific Ocean: paleomagnetic and tectonic implications, Geophys. Res. Lett., 19, 693-696, 1992.

Nishiyama, S., Mantle hydrology in a subduction zone: A key to episodic geologic events, double Wadati-Benioff zones and magma genesis, Mathematical Seismology VII, Rep. Stat. Math. Inst., 34, 31-67, 1992.

Ohkura, T., Structure of the upper part of the Philippine Sea plate estimated by later phases of upper mantle earthquakes in and around Shikoku, Japan, Tectonophys., 321, 17-36, 2000.

Okino, K., Y. Shimakawa, and S. Nagano, Evolution of the Shikoku Basin, J. Geomag. Geoelectr., 46, 463-479, 1994.

Peacock, S. M., The importance of blueschist - eclogite dehydration reactions in subducting oceanic crust, Geol. Soc. Am. Bull., 105, 684-694, 1993.

Peacock, S. M., Are the lower planes of double seismic zones caused by serpentine dehydration in subducting oceanic mantle?, Geol. Soc. Am. Bull., 29, 299-302, 2001

Peacock, S. M. and K. Wang, Seismic consequences of warm versus cool subduction metamorphism: Examples from southwest and northeast Japan, Science, 286, 937-939, 1999.

Raleigh, C. B. and M. S. Paterson, Experimental deformation of serpentinite and its tectonic implications, J. Geophys. Res., 70, 3965-3985, 1965 .

Sano, Y. and H. Wakita, Geographical distribution of ${ }^{3} \mathrm{He} /{ }^{4} \mathrm{He}$ rations in Japan: implications for arc tectonics and incipient magmatism, J. Geophys. Res., 90, 8729-8741, 1985.

Sekiguchi, S., Three dimensional P and S velocity structures of uppermost mantle beneath Kanto, Tokai and Chubu districts, Japan, Jisin, 53, 137151,2000

Seno, T., Tectonic evolution of the West Philippine Basin, Modern Geology, 12, 481-495, 1988.

Seno, T. and S. Maruyama, Paleogeographic reconstruction and origin of the Philippine Sea, Tectonophys., 102, 53-84, 1984.

Seno, T. and Y. Yamanaka, Double seismic zones, deep compressional trench-outer rise events and superplumes, in Subduction Top to Bottom, edited by G. E. Bebout, D. W. Scholl, S. H. Kirby, and J. P. Platt, Geophys. Monogr., 96, 347-355, Am. Geophys. Union, Washington, D. C., 1996.

Seno, T., S. Stein, and A. E. Gripp, A model for the motion of the Philippine Sea plate consistent with NUVEL-1 and geological data, J. Geophys. Res., 98, 17941-17948, 1993.

Seno, T., T. Sakurai, and S. Stein, Can the Okhotsk plate be discriminated from the North American plate?, J. Geophys. Res., 101, 11305-11315,
1996.

Shimizu, H., K. Uyehira, and K. Goto, The detailed structure of the deep seismic zone and focal mechanism solutions from the western end of Chugoku-Shikoku district to the Kyushu district, Abstr. Seism. Soc. Jpn., B39, 2000 (in Japanese).

Sleep, N. H., The double seismic zone in downgoing slabs and the viscosity of the mesosphere, J. Geophys. Res., 84, 4565-4571, 1979.

Suyehiro, K., N. Takahashi, Y. Ariie, Y. Yokoi, R. Hino, M. Shinohara, T. Kanazawa, N. Hirata, H. Tokuyama, and A. Taira, Continental crust, crustal underplating, and low-Q upper mantle beneath an oceanic Island arc, Science, 272, 390-392, 1996.

Takahashi, N., K. Suyehiro, and M. Shinohara, Implications from the seismic crustal structure of the northern Izu-Bonin arc, Isl. Arc, 7, 383-394, 1998.

Tatsumi, Y., Migration of fluid phases and genesis of basalt magmas in subduction zones, J. Geophys. Res., 94, 4697-4707, 1989.

Ulmer, P. and V. Trommsdorff, Serpentine stability to mantle depths and subduction-related magmatism, Science, 268, 858-859, 1995.

Wakita, H., Y. Sano, and M. Mizoue, High ${ }^{3} \mathrm{He}$ emanation and seismic swarms observed in a nonvolcanic, forearc region, J. Geophys. Res., 92, 12539-12546, 1987.

Wang, K., R. D. Hyndman, and M. Yamano, Thermal regime of the Southwest Japan subduction zone: effects of age history of the subducting plate, Tectonophys., 248, 53-69, 1995.

Yamano, M., Recent heat flow studies in and around Japan, Terrestrial heat flow and geothermal energy in Asia, in Terrestrial Heat Flow and Geothermal Energy in Asia, edited by M. L. Gupta and M. Yamano, pp. 173-201, Oxford \& IBH Publishing Co., New Delhi, 1995.

Yamazaki, F. and T. Ooida, Configuration of subducted Philippine Sea plate beneath the Chubu District, central Japan, Jisin, 38, 193-201, 1985 (in Japanese).

Zhao, D. and H. Negishi, The 1995 Kobe earthquake: Seismic image of the source zone and its implications for the rupture nucleation, J. Geophys. Res., 103, 9967-9986, 1998.

Zhao, D., K. Asamori, and H. Iwamori, Seismic structure and magmatism of the young Kyushu subduction zone, Geophys. Res. Lett., 27, 20572060, 2000a.

Zhao, D., F. Ochi, A. Hasegawa, and A. Yamamoto, Evidence for the location and cause of large crustal earthquakes in Japan, J. Geophys. Res., 105, 13579-13594, 2000b.

Zhao, D., M. Di, F. Ochi, and T. Seno, Dehydration and earthquakes of the Philippine Sea slab (2) Evidence from seismic tomography, Abstr. Seism. Soc. Jpn., P141, 2000c.

T. Seno (e-mail: seno@eri.u-tokyo.ac.jp), D. Zhao, Y. Kobayashi, and M. Nakamura 